Jurdimas (Jurnal Pengabdian Kepada Masyarakat) Royal

Vol. 2 No. 1, Jan 2019, hlm. 39 - 42

ISSN 2614-7912 (Print)

DOI: https://doi.org/10.33330/jurdimas.v2i1.318

ISSN 2622-3813 (Online)

Available online at https://jurnal.stmikroyal.ac.id/index.php/jurdimas

\title{
PENINGKATAN PEMBELAJARAN MELALUI BLOGSPOT BAGI GURU SEKOLAH MENENGAH PERTAMA NEGERI 6 KISARAN
}

\author{
Afdhal Syafnur, Rika Nofitri \\ Program Studi Sistem Informasi,STMIK Royal Kisaran \\ e-mail : afdhal23@gmail.com
}

\begin{abstract}
The development of information and communication technology as well as the development of times is very fast, so it does not rule out the possibility of influence on human life, especially in everyday life using technology. Blog is one of the media that can help in delivering information quickly and up to date. The use of an easy blog can help in the teaching and learning process so that it can be easier to share knowledge outside of school hours through media blogs.
\end{abstract}

Keywords: information, learning, blog.

\begin{abstract}
Abstrak: Semakin berkembangnya teknologi informasi dan komunikasi serta dengan perkembangan zaman yang sangat cepat, sehingga tidak menutup kemungkinan adanya pengaruh pada kehidupan manusia terutama pada kehidupan keseharian dengan menggunakan teknologi. Blog merupakan salah satu media yang dapat membantu dalam penyampaian informasi yang cepat dan up to date. Penggunaan blog yang mudah dapat membantu dalam proses belajar mengajar sehingga dapat lebih mudah berbagi pengetahuan di luar jam belajar sekolah melalui media blog.
\end{abstract}

Kata kunci: informasi,pembelajaran,blog

\section{PENDAHULUAN}

\section{Perkembangan teknologi saat ini sudah sangat membantu para pengguna internet khususnya penggunaan teknologi informasi. Dengan penggunaan internet dapat mempermudah mengakses informasi dengan cepat dan mudah serta lebih efisien. Sekolah menengah pertama negeri 6, merupakan sekolah yang ada di asahan yang telah memanfaatkan teknologi IT sebagai media belajar. Dengan adanya dukungan laboratorium komputer dan fasilitas internet pada area sekolah memungkin bagi guru dan siswa untuk dapat lebih mudah dalam proses sharing mengajar serta mendapatkan informasi belajar}

melalui sebuah blog.

Salah satu layanan blog gratis yang sangat populer adalaha blogspot. Blogspot merupakan salah satu penyedia akun website bebas biaya dimana kita dapat posting,sharing dan lain sebagainya. Akun blog merupakan akun google karena saat login kita akann menggunakan akun google. Sasaran pengabdian masyarakat yang dilaksanakan ini adalah bagi guru SMP Negeri 6 .

Rumusan masalah pengabdian masyarakat ini adalah sebagai berikut :

a. Bagaimana guru dapat memanfaatkan teknologi internet sebagai media pembelajaran.

b. Bagaimana guru dapat membuat blog pribadi untuk berbagi materi 
Jurdimas (Jurnal Pengabdian Kepada Masyarakat) Royal

Vol. 2 No. 1, Jan 2019, hlm. 39 - 42

ISSN 2614-7912 (Print)

DOI: https://doi.org/10.33330/jurdimas.v2i1.318

ISSN 2622-3813 (Online)

Available online at https://jurnal.stmikroyal.ac.id/index.php/jurdimas

pelajaran di sekolah.

Tujuan dari kegiatan ini adalah memberi pemahaman kepada peserta dalam bentuk workshop mengenai konsep - konsep dan cara membuat blogspot dengan mudah.

Adapun manfaat dari pelaksanaan kegiatan pengabdian kepada masyarakat ini adaalah :

a. Peserta dapat memahami dan membuat blog pribadi sebagai sarana untuk sharing materi pembelajaran di sekolah.

b. Sebagai wadah berbagi ilmu bagi dosen STMIK Royal Kisaran dalam pengabdian kepada masyarakat

Blog merupakan singkatan dari web $\log$ adalah bentuk aplikasi web yang berbentuk tulisan-tulisan (yang dimuat sebagai posting) pada sebuah halaman web. Tulisan-tulisan ini seringkali dimuat dalam urutan terbalik (isi terbaru dahulu sebelum diikuti isi yang lebih lama), meskipun tidak selamanya demikian. Situs web seperti ini biasanya dapat diakses oleh semua pengguna Internet sesuai dengan topik dan tujuan dari si pengguna blog tersebut.

Media blog pertama kali dipopulerkan oleh Blogger.com, yang dimiliki oleh Pyra Labs sebelum akhirnya diakuisisi oleh Google pada akhir tahun 2002. Semenjak itu, banyak terdapat aplikasi-aplikasi yang bersifat sumber terbuka yang diperuntukkan kepada perkembangan para penulis blog tersebut. Blog mempunyai fungsi yang sangat beragam, mulai dari sebuah catatan harian, media publikasi dalam sebuah kampanye politik, sampai dengan program-program media dan perusahaan-perusahaan. Sebagian blog dipelihara oleh seorang penulis tunggal, sementara sebagian lainnya oleh beberapa penulis. Banyak juga blog yang memiliki fasilitas interaksi dengan para pengunjungnya, seperti menggunakan buku tamu dan kolom komentar yang dapat memperkenankan pengunjungnya untuk meninggalkan komentar atas isi dari tulisan yang dipublikasikan, namun demikian ada juga blog yang bersifat sebaliknya (non-interaktif).

\section{METODE}

Metode pelaksanaan dalam pengabdian kepada masyarakat ini adalah dengan cara melaksanakan kegiatan pelatihan dalam bentuk workshop serta menjelaskan teori teori dasar dalam pembuatan blog.

\section{PEMBAHASAN}

Berikut adalah beberapa tahapan dalam pembuatan blog

a. Buatlah account terlebih dahulu pada gmail. Contoh dapat dilihat pada gambar di bawah ini..

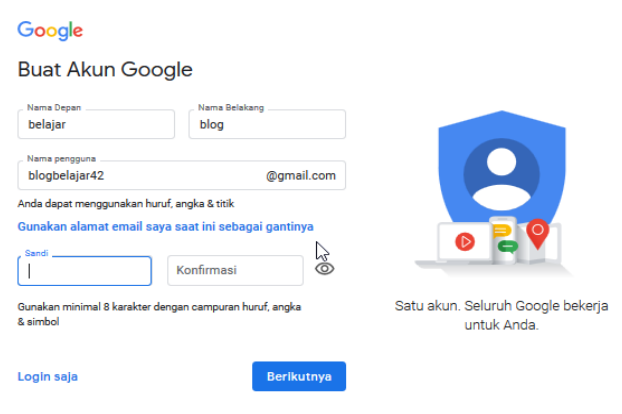

Gambar 1. Proses buat akun google 
Jurdimas (Jurnal Pengabdian Kepada Masyarakat) Royal

Vol. 2 No. 1, Jan 2019, hlm. 39 - 42

ISSN 2614-7912 (Print)

DOI: https://doi.org/10.33330/jurdimas.v2i1.318

ISSN 2622-3813 (Online)

Available online at https://jurnal.stmikroyal.ac.id/index.php/jurdimas

b. Berikutnya isi biodata sesusai yang ada pada form.

c. Klik tombol setuju untuk melanjutkan proses berikutnya.
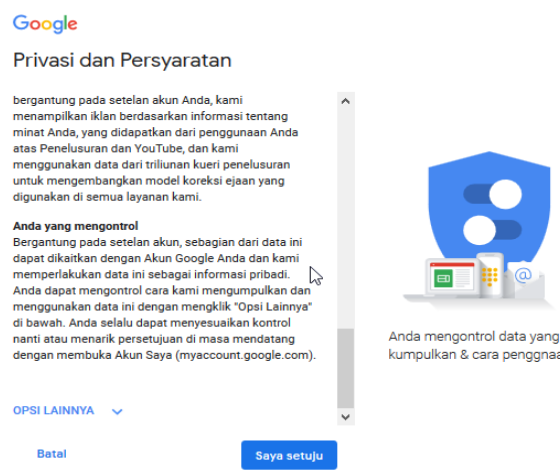

Anda mengontrol data yang kami Anda mengontrol dota yang kami

Gambar 2. Proses pembuatan akun google
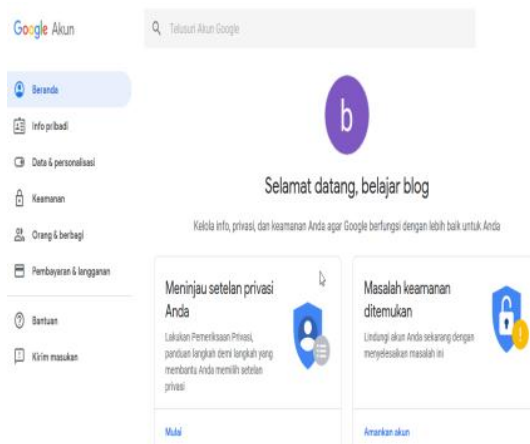

Gambar 3. Proses buat akun google

d. Selanjut pilih menu seperti pada gambar di bawah ini dan pilih option lainnya yang ada pada bagian bawah.

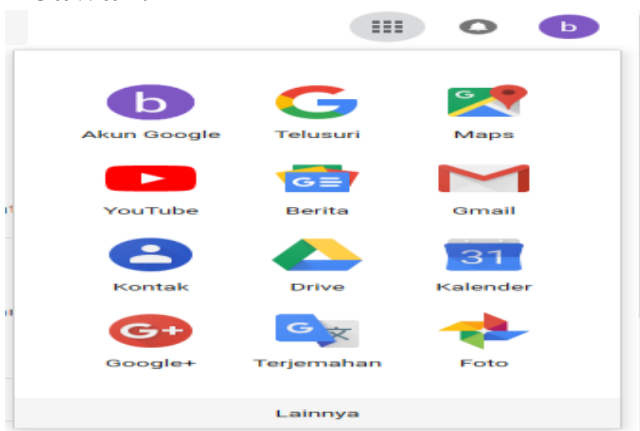

Gambar 4.Proses pembuatan blog e. Pilih bloger seperti pada gambar dibawah ini.

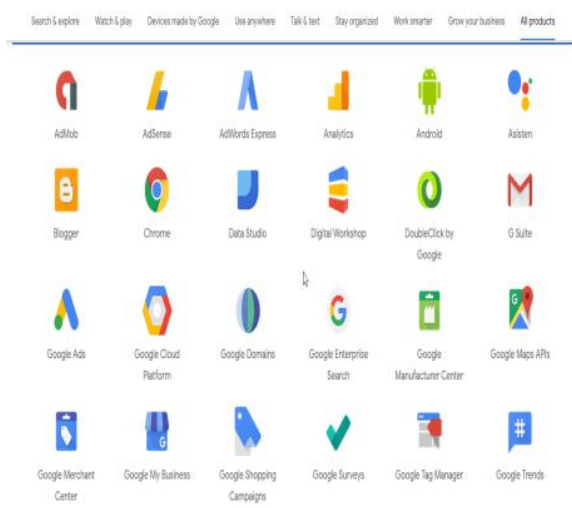

Gambar 5.Proses pembuatan blog

f. Setelah itu akan muncul tampilan sebagai berikut dan piilih buat blog.

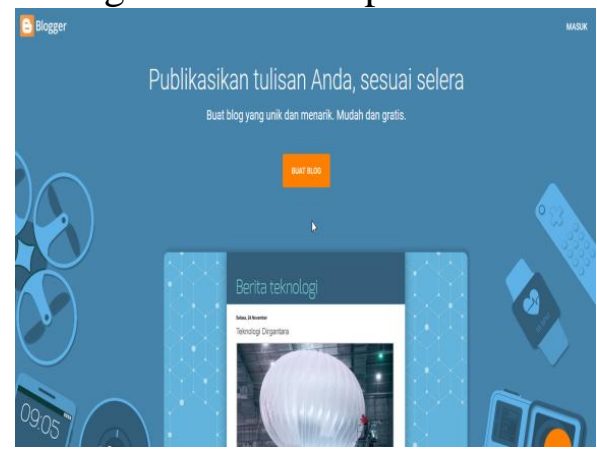

Gambar 6.Proses pembuatan blog

g. Selanjutnya isi nama tampilan blog seperti gambar dibawah

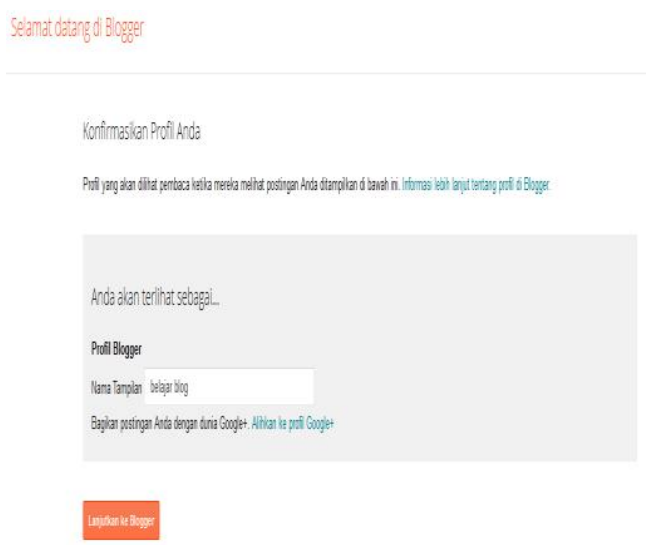

Kemudian pilih buat blog 
Jurdimas (Jurnal Pengabdian Kepada Masyarakat) Royal

Vol. 2 No. 1, Jan 2019, hlm. 39 - 42

ISSN 2614-7912 (Print)

DOI: https://doi.org/10.33330/jurdimas.v2i1.318

ISSN 2622-3813 (Online)

Available online at https://jurnal.stmikroyal.ac.id/index.php/jurdimas
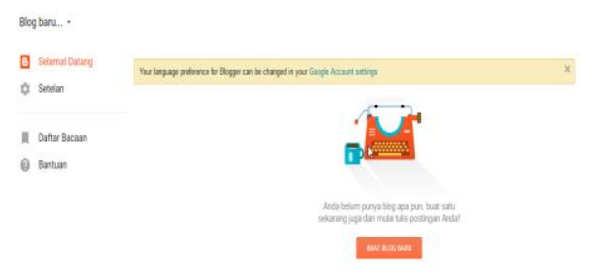

Gambar 7.Proses pembuatan blog

h. Selanjutnya isi judul dan alamat blog dan alamat blog dan pastikan alamat blog tersedia.

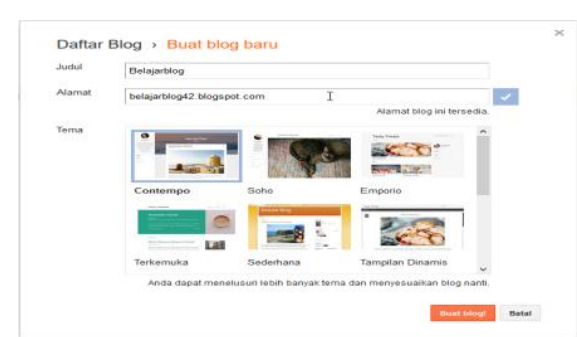

.Gambar 8.Proses pembuatan blog

Sampai pada tahap ini blog terlah selesai dibuat, kemudian silahkan coba untuk melakukan posting berita yang telah disediakan pada menu menu yang ada pada blog.

\section{SIMPULAN}

Kegiatan tridharma pengabdian kepada masyarakat yang dilaksanakan bagi guru pada sekolah menengah pertama negeri 6 kisaran berjalan dengan baik. Workshop dan pelatihan pembuatan blog ini memberikan wawasan tambahan kepada guru guna meningkatkan metode pembelajaran dan manfaatkan teknologi informasi yang berada di lingkungan sekolah. Sehingga pembelajaran ini jadi lebih menarik, karena siswa dapat melihat dan mengulang materi yang telah dipelajari melalui blog yang telah dibuat.

\section{UCAPAN TERIMA KASIH}

Kegiatan pengabdian kepada masyarakat tidak terlepas dari dukungan yang telah diberikan oleh pihak sekolah sebagai tempat kami melaksanakan pelatihan pembuatan blog. Ucapan terima kasih yang sebesarnya kepada Bapak Syafnil,S.Pd selaku kepala sekolah serta guru guru yang telah mneyambut kami dengan baik. Terima Kasih juga kami sampaikan kepada Lembaga penelitian dan pengabdian STMIK Royal Kisaran.

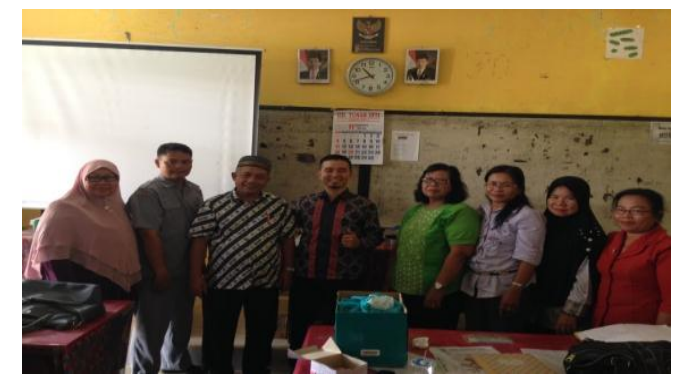

\section{DAFTAR PUSTAKA}

Edyutomo."cara membuat blog di blogger atau blogspot untuk pemula". 20 desember2018".https://edyutomo.c om/ cara-membuat-blogger/.

Bambang Winarso."panduan pemula cara membuat blog gratis di blogger".21 Desember 2018”. https://dailysocial.id/post/caramembuat-blog-gratis-di-bloggercom/

Yasha."cara membuat blog dan tips untuk para blogger pemula". 21 Desember 2018 .https://www.dewaweb.com/blog/c ara-membuat-blog/ 